\title{
Artikel
}

\section{Verzet onder juristen tegen 'onrechtvaardig recht' in de Tweede Wereldoorlog, in het bijzonder tegen de antisemitische maatregelen van de bezetter}

Prof. mr. C.J.H. (Corjo) Jansen*

\section{Inleiding}

$\mathrm{Na}$ de bevrijding ontstond al snel het beeld dat 'de' Nederlanders zich tijdens de oorlog heldhaftig hadden verzet tegen de Jodenvervolging en het nationaalsocialistische onrecht. ${ }^{1}$ De naoorlogse berichten over de moord op meer dan 102.000 Nederlandse Joden brachten dit zelfbeeld nauwelijks aan het wankelen. Dat werd anders, toen in de jaren zestig van de vorige eeuw bleek dat de nazi's gedurende de Tweede Wereldoorlog uit geen enkel land in West-Europa zo veel Joden hadden gedeporteerd en omgebracht als uit Nederland. Het cijfer is - nog steeds - onthutsend te noemen: $79 \%$ van de Nederlandse Joden is tijdens de oorlog weggevoerd. ${ }^{2}$ De Leidse historicus B. van der Boom wijst erop dat dit

Corjo Jansen is hoogleraar Rechtsgeschiedenis en Burgerlijk recht aan de Radboud Universiteit Nijmegen.

1. Zie recent nog 'Ruttes excuses markeren omslag', NRC Handelsblad 27 januari 2020, voorpagina.

2. P. Romijn, 'De oorlog (1940-1945)', in: Hans Blom e.a. (red.), Geschiedenis van de Joden in Nederland, Amsterdam: Balans 2017, p. 404; K. Happe, Veel valse hoop. De Jodenvervolging in Nederland 1940-1945, Amsterdam/Antwerpen: Atlas Contact 2018, p. 16, spreekt over 75\%; B. van der Boom, 'Wij weten niets van hun lot'. Gewone Nederlanders en de Holocaust, Amsterdam: Boom 2012, noemt op p. 11 het percentage van $73 \%$ vermoorde Joden. In België bedroeg het percentage weggevoerde Joden $40 \%$ en in Frankrijk 38\%. Zie G. Luijters, R. Schütz \& M. Jongman (red.), De deportaties uit Nederland 1940-1945, Amsterdam: Nieuw Amsterdam 2018). zelfbeeld mede kon rijzen, omdat de meeste Nederlanders antinazi waren geweest en zij vaak niets moesten hebben van de antisemitische maatregelen. ${ }^{3}$

Uit wetenschappelijk onderzoek is echter duidelijk geworden dat deze afkeer van het nationaalsocialisme vele ambtenaren en juristen er niet van heeft weerhouden (tot diep in de oorlog) door te werken. Zij beriepen zich daarvoor op de Aanwijzingen van de Nederlandse regering uit $1937 .{ }^{4}$ Aanwijzing 1 gaf als algemene regel dat de personen, werkzaam bij overheidsorganen, ter plaatse behoorden te blijven. 'Zij zullen in het belang der bevolking [cursivering in origineel] er naar streven, dat het bestuur ook onder de gewijzigde omstandigheden zoo goed mogelijk zijn taak blijft vervullen.' Het criterium 'in het belang der bevolking' kende een uitwerking in Aanwijzing 31:

'De reden, dat ambtenaren in functie blijven is deze, dat dit in het belang is van de bevolking; het nadeel, dat zij daardoor mede het belang van den bezetter dienen, is in het algemeen geringer dan het grootere nadeel, dat voor de bevolking zou voortvloeien uit het niet meer functionneeren van het eigen bestuurs-

3. Van der Boom, 'Wij weten niets van hun lot', p. 9-10, conclusie op p. 417: de afkeer van de door de bezetter opgedrongen anti-Joodse maatregelen was fel en algemeen.

4. Over deze aanwijzingen o.a.: P.E. Mazel, In naam van het Recht... De Hoge Raad en de Tweede Wereldoorlog, Arnhem: Gouda Quint 1984, p. 24-27; M. Verburg, Geschiedenis van het Ministerie van Justitie 1940-1945. Een departement in oorlogstijd, Amsterdam: Boom uitgevers 2016, p. 14 e.v. 
apparaat. Indien echter de ambtenaar, door in functie te blijven, zoodanige diensten aan den vijand zou bewijzen, dat deze grooter kunnen worden geacht dan het nut, dat voor de bevolking aan zijn aanblijven is verbonden, dan zal hij zijn post moeten verlaten.'

De Aanwijzingen zijn in de loop van de oorlogsjaren voor vele (hoge) ambtenaren en juristen de grondslag geweest om door te werken, op ministeries en universiteiten, bij provincie en gemeente, politie en spoorwegen, in de rechterlijke macht, etc.

Daarbij kwam nog dat de bezetter juridisch gezien in beginsel de bevoegdheid had verordeningen uit te vaardigen. Hij moest daarbij wel - 'behoudens volstrekte verhindering' - de in het bezette land geldende wetten eerbiedigen. Wat 'behoudens volstrekte verhindering' betekende, was niet duidelijk. De wetgevende bevoegdheid van de bezetter berustte op artikel 43 uit het Verdrag nopens de wetten en gebruiken van den oorlog te land (Landoorlogverdrag) van 1907 en de daarbij horende bijlage, het Landoorlogreglement van 1907 (Stb. 1910, 73):

'Wanneer het gezag van de wettelijke overheid feitelijk is overgegaan in handen van dengene, die het gebied heeft bezet, neemt deze alle maatregelen, die in zijn vermogen staan, ten einde voor zoveel mogelijk de openbare orde en het openbare leven te herstellen en te verzekeren en zulks, behoudens volstrekte verhindering, met eerbiediging van de in het land geldende wetten.'

De Leidse hoogleraar B.M. Telders (1903-1945) schreef in het Nederlands Furistenblad van 1940 dat de bezetter op grond van artikel 43 Landoorlogverdrag niet alleen bevoegd, maar zelfs verplicht was tot de uitoefening van de wetgevende macht. Hij kon deze bevoegdheden overdragen aan Nederlandse organen, zoals de secretarissengeneraal op de departementen. ${ }^{6}$ Volgens Telders waren de eerste Duitse verordeningen in overeenstemming met de letter en de geest van het Landoorlogreglement. Hij betoogde dan ook in de Nieume Rotterdamsche Courant van 8 juni 1940 dat een ambtenaar - zo lang hij in functie bleef - zich onvoorwaardelijk als goed en loyaal ambtenaar moest gedragen. Dergelijk gedrag sloot een stipte naleving van wetten en verordeningen in, ook voor zover deze dus van de bezetter afkomstig waren. ${ }^{7}$

5. Mazel, In naam van het Recht, p. 20-22; P.J.M. von Schmidt auf Altenstadt, 'De Rechterlijke Macht in oorlogstijd; zwijgen is fout', Trema 2004 , p. 277-278. Op verzoek van enige lezers publiceerde het $N J B$ art. 42-56 van het Landoorlogreglement. Zie NJB 1940, p. 475-476.

6. Zie B.M. Telders, 'Oorlogsverordeningen (NJB 1940)', in: Verzamelde Geschriften van Prof. Mr. B.M. Telders, IV, 's-Gravenhage: Martinus Nijhoff 1947, p. 291 e.v. Zie over de wetgevende bevoegdheid in Nederland tijdens de bezetting; J.H.P. Bellefroid, Beknopt overzicht der staatsinrichting van Nederland tijdens de bezetting, Nijmegen-Utrecht: Dekker \& Van de Vegt 1941, p. 4 e.v. en p. 11 e.v

7. B.M. Telders, 'Eerlijke medewerking gevraagd en geboden (NRC 8 juni 1940, Avondblad)', in: Verzamelde Geschriften van Prof. Mr. B.M. Telders, IV, p. 305. De ambtenaar kon zijn medewerking met de bezetter beëindigen, indien voortzetting van de samenwerking tegen zijn gewe-
De Nederlandse socioloog C.J. Lammers heeft voorts gewezen op de verschillende wijzen waarop de bezetter in 1940-1945 zijn machtsuitoefening in Nederland heeft kunnen schragen. Behalve over fysieke middelen (leger, politie, opsporings- en geheime diensten) beschikte hij over sociaaleconomische dwangmiddelen (zoals ontslag, demotie en berisping) en sociaaleconomische lokmiddelen (zoals promotie, betere beloning en toekenning van voorrechten). Daarnaast droegen de Aanwijzingen van de Nederlandse regering en het Landoorlogreglement in hoge mate bij aan de schijn dat de verordeningen van de Duitse bezetter en de besluiten van de secretarissengeneraal afkomstig waren van het legale gezag. ${ }^{8}$ Deze schijn heeft een verzetshouding tegen de bezetter en het nazi-onrecht bemoeilijkt.

In deze bijdrage sta ik stil bij het verzet van Nederlandse juristen in het bijzonder tegen de antisemitische maatregelen, die ik als voorbeelden bij uitstek zie van 'onrechtvaardig recht'. Verzet kan allerlei vormen aannemen: van een 'simpel' protest, de ontslagname door een ambtenaar, de weigering van een rechter een antisemitische bepaling toe te passen tot het onderdak bieden aan een Joodse collega en zelfs het opnemen van de wapens. Ik ga niet dieper in op deze verschillende vormen van verzet. In de volgende paragrafen behandel ik kort het vooroorlogse protest van Nederlandse juristen tegen het antisemitisme en voorts het universitaire verzet, het verzet van de rechterlijke macht, de advocatuur en het notariaat tegen (vooral) de anti-Joodse maatregelen tijdens de bezetting. In de afgelopen jaren is hierover veel literatuur verschenen. Daarvan maak ik dankbaar gebruik.

\section{Vooroorlogs verzet tegen het antisemitisme}

Het antisemitisme was een van de pijlers van het naziregime, dat in januari 1931 in Duitsland aan de macht kwam. Centraal in de nationaalsocialistische leer stonden het rassen- en het etnische beginsel. 'Deutsches Blut, deutsche Ehre und Erbgesundheit sind rein $\mathrm{zu}$ halten und zu wahren. Sie sind die Grundkräfte des deutschen Volkrechts. ${ }^{9}$ De Joden waren als uitvloeisel

ten indruiste. Zie B.M. Telders, 'Leiding (Het Liberale Weekblad 27 september 1940)', in: Verzamelde Geschriften van Prof. Mr. B.M. Telders, V, 's-Gravenhage: Martinus Nijhoff 1949, p. 242 e.v. Ook: 'De Regeeringsbevoegdheden in Nederland t.a.v. de rechtspraak', NJB 1940, p. 505. De anonieme auteur van het stuk riep de rechterlijke ambtenaren op de verordeningen van Rijkscommissaris A. Seyss-Inquart (1892-1946) loyaal uit te voeren.

8. C.J. Lammers, 'Macht en gezag van de Duitse bezetter', in: C.J. Lammers, Vreemde overheersing. Bezetten en bezetters in sociologisch perspectief, Amsterdam: Uitgeverij Bert Bakker 2005, p. 63-66. SeyssInquart was na twee jaar bezetting nog steeds buitengewoon tevreden over de gehoorzaamheid van de Nederlandse ambtenaren (p. 61).

9. A. Buschmann, Nationalsozialistische Weltanschauung und Gesetzgebung 1933-1945, I, Wenen: Verlag Österreich 2015, p. 16-18; S. Meder, Rechtsgeschichte, 5. Aufl., Keulen etc.: Böhlau Verlag 2014, p. 412 e.v. 
van deze beginselen een van de eerste groepen slachtoffers van de nazi's. Op grond van punt 4 van het Partijprogramma van de NSDAP (1920) konden Joden geen staatsburger van het 'nieuwe' Duitsland zijn. Zij behoorden niet tot de 'arische' volksgemeenschap. Duitse wetten van april 1933 weerden Joodse rechters uit hun ambt en Joodse advocaten uit hun beroep. Ook de Duitse ambtenaren van Joodse huize, onder wie talloze hoogleraren, kregen ontslag. Het schrijven in tijdschriften werd de Duitse Joodse juristen in de loop van 1933 onmogelijk gemaakt. ${ }^{10}$ Volgens de Duitse rechtshistoricus Jan Schröder had "die "Rassen-" und "Gemeinschafts"-Ideologie [...] ebensolche Realität wie das Führerprinzip. Die Elemente gehören zusammen und sie behersschen (...) nicht nur die Rechtsquellenlehre, sondern auch die Theorie der Gesetzesauslegung und der Rechtswissenschaft.' 11

Het rassen- en het etnische beginsel kregen een uitwerking in twee van de drie Neurenberger rassenwetten, afgekondigd op 15 september 1935 tijdens de 'Rijkspartijdag van de Vrijheid'. ${ }^{12}$ De eerste wet was de Reichsbürgergesetz. De kern van de wet was dat alleen personen van Duits of verwant bloed Duits staatsburger konden zijn. De tweede wet heette Gesetz zum Schutze des deutschen Blutes und der deutschen Ehre. Zij verbood huwelijken en buitenechtelijk seksueel verkeer tussen Joden en onderdanen van Duitse of verwant bloed. Handelen in strijd met deze verboden leverde straf op. De Neurenberger rassenwetten trokken de aandacht van juridisch

Nederland. ${ }^{13}$ Zij leidden tot protest. De toenmalige vicepresident en latere president van de Hoge Raad, L.E. Visser (1871-1942), was in 1935 een van de sprekers tijdens een grote, door het Comité voor Bijzondere Joodsche Belangen georganiseerde protestvergadering in een tjokvolle Amsterdamse Apollohal (die ruimte bood aan zesduizend mensen) tegen de Neurenberger rassenwetten. Ik citeer uit de toespraak van Visser:

'Tot dusver was de feitelijke toestand ook volgens de Duitsche wet onrecht.' (...) ' $\mathrm{Nu}$ is dit alles anders. Ook dit onrecht is thans door de wet bekrachtigd en

10. Gesetz zur Wiederherstellung des Berufsbeamtentums vom 7. April 1933; Gesetz über die Zulassung zur Rechtsanwaltschaft vom 7. April 1933; 'Richtlinien der Schriftleitung', Juristische Wochenschrift 1933, p. 1689 e.v.

11. J. Schröder, Rechtswissenschaft in Diktaturen. Die juristische Methodenlehre im NS-Staat und in der DDR, München: C.H. Beck 2016, p. 14-15, p. 57-58.

12. Buschmann, Nationalsozialistische Weltanschauung und Gesetzgebung 1933-1945, I, p. 38-39. De derde wet heette de Reichsflaggengesetz. Zij bepaalde dat de hakenkruisvlag de enige Duitse nationale vlag zou zijn.

13. P.G.M. van Meeuwen, 'Het huwelijksverdrag en de nieuwe Duitsche wet tot regeling van de positie der Joden', NJB 1935, p. 483-486; H.L. van Zanten, 'De Duitsche "Jodenwet" in Nederland', NJB 1935 , p. 495-496; 'De "Wetten van Neurenberg"', NJB 1935, p. 662-653; I. Kisch, 'Het Duitsche verbod van gemengde huwelijken', W. 1935/12960, p. 1-2; J. Loonstijn, ‘De Duitsche jodenwetgeving op het stuk van huwelijk', W. 1935/12965, p. 8 (met nawoord van Kisch); I. Kisch, 'Gemengde huwelijken van Duitschers met niet-Joden', NJB 1936, p. 167-169; J.W.M. Schröder, ‘De Duitsche Rassen- en huwelijkswetgeving bezien in het licht van het Nederlandsch Internationaal Privaatrecht', NJB 1936, p. 1009 e.v., p. 1037 e.v. dus dáár recht geworden.' (...) 'Wat vooral ieder beklemt is de geest, die uit die wetten spreekt. Die wetten symboliseeren a.h.w. de volkomen uitscheiding der Joden uit het Duitsche staatsleven, hun onherroepelijke ontrechting, het terugzetten van de klok door een land, dat eens - en terecht - er prat op ging aan de spits der beschaving te staan.' (...) 'De wetgeving stapelt beleediging op onrecht; het is niets, dan het kwellen en beleedigen van een kleine en weerlooze bevolkingsgroep op een wijze, welke in de geschiedenis moeilijk haar weerga vindt. ${ }^{14}$

Aan de radicale verzetshouding van Visser, vooral ook tijdens de oorlog, hebben recente auteurs de nodige aandacht besteed. ${ }^{15}$ Visser schrok er niet voor terug de Duitsers te misleiden, bijvoorbeeld door zijn boekhouding 'te vervalsen'. Hij zocht in juni 1941 - in strijd met zijn principes - rechtstreeks contact met H.A. Rauter (1895-1949), de Höherer SS-und Polizeiführer in Nederland, vanwege de stroom aan overlijdensberichten van een aantal honderden naar Mauthausen gedeporteerde Joodse jongemannen. Het mocht niet baten. Rauter ontving geen Joden. ${ }^{16}$

De lotgevallen van de Duitse Joden lieten de Nederlandse juristen (gelukkig) niet onberoerd. ${ }^{17} \mathrm{Zij}$ riepen in 1934 de Nederlandse regering op om de rechtsbescherming van vreemdelingen te verbeteren. Het ging vooral om Joodse vluchtelingen naar Nederland. ${ }^{18} \mathrm{Zij}$ waren na de 'Reichskristallnacht' van begin november 1938 van huis en haard verdreven en zochten hun toevlucht in Nederland. Ons land hield echter de grenzen dicht. De Nederlandse grenswachten hadden de opdracht vluchtelingen die niet over de juiste papieren beschikten, zonder pardon terug te sturen naar Duitsland. Opnieuw volgde een petitie van een aantal juristen (en medici) aan de later in Buchenwald omgekomen Minister van Justi-

14. 'Joodsch Protest. Tegen de nieuwe Duitsche wetten.', De Tijd 18 september 1935, p. 4; 'Tegen ontrechting der Joden', Algemeen Handelsblad Vrijdag 20 september 1935, Ochtendblad, p. 6; 'De Jodenwetten in Duitschland', Het Vaderland 20 september 1935, Ochtendblad, p. 3.

15. Ernst Hirsch Ballin, Tegen de stroom. Over mannen en ideeën die hoop geven in benarde tijden, Amsterdam: Querido 2016, p. 41 e.v.; C.J.H. Jansen, 'Facetten uit het bewogen leven van Lodewijk Ernst Visser (1871-1942)', in: L. de Groot-van Leeuwen e.a. (red.), Het verhaal van de rechter. Over de plaats van de rechter in literatuur, samenleving en rechtszaal. Liber amicorum J.D.A. den Tonkelaar, Deventer: Wolters Kluwer 2018, p. 143 e.v.; M. Schwegman, 'Niet domweg als Joden ten ondergaan'. Lodewijk Ernst Visser, de eer van Joodse Nederlanders en hun verzet, Vijfde Mr. L.E. Visser-lezing 13 juni 2019 (raadpleegbaar via internet).

16. Schwegman, 'Niet domweg als Joden ten ondergaan', p. 4-5. Zie ook T. Gerritse, Rauter. Himmlers vuist in Nederland, Amsterdam: Boom 2018, p. 213.

17. Voor het navolgende: C.J.H. Jansen, 'Joodse vluchtelingen en de Nederlandse 'gastvrijheid' in de jaren dertig van de vorige eeuw', RMThemis 2018/6, p. 217 e.v.

18. Tot de ondertekenaars behoorden onder anderen de hoogleraren, rechters en advocaten D. van Embden, F.J.A. Huart, G.C.J.D. Kropman, M. Mendels, E.H. von Baumhauer, G. van den Bergh, W.A. Bonger, H.O. Drilsma, H. Frijda, D. Hazewinkel-Suringa, P.W. Kamphuisen, F. Kranenburg, R. Kranenburg, M.G. Levenbach, J.C. van Oven, F.G. Scheltema, P. Scholten, B. Stokvis en C.W. de Vries. Zie 'Rechtsbescherming voor vreemdelingen', Soerabaiasch Handelsblad 22 juni 1934, Vierde blad. 
tie, C. Goseling (1891-1941). Zij kwamen in verzet tegen de behandeling van de Joodse vluchtelingen en verzochten hem zo veel mogelijk asiel te verlenen aan hen die als gevolg van de gebeurtenissen in Duitsland hun toevlucht in Nederland hadden gezocht. ${ }^{19}$

\section{Het universitaire verzet}

Het universitaire verzet tegen de antisemitische maatregelen kwam tijdens de bezetting op gang naar aanleiding van de ariërverklaring van oktober 1940 . Zij was gebaseerd op een verordening van 13 september 1940 van Rijkscommissaris Seyss-Inquart. Deze verordening, die een inbreuk betekende op artikel 5 van de toenmalige Grondwet, maakte het mogelijk dat de rechtspositie van ambtenaren en overig personeel in rijksdienst en in het bijzonder de voorwaarden waaronder zij konden worden aangesteld of ontslagen, een regeling kreeg die afweek van het tot op dat moment geldende recht $(\S 1) .{ }^{20}$ Begin oktober 1940 ontvingen alle ambtenaren een formulier waarop zij moesten aangeven of zij Joodse ouders of grootouders hadden of dat zij waren getrouwd of verloofd met een Joodse partner. Bijna iedere ambtenaar stuurde de formulieren ingevuld terug. Bijna 98\% van de ambtenaren, die onder het Ministerie van Justitie vielen, vulde de ariërverklaring in. Bij het Amsterdamse ambtenarencorps, met een omvang van 24.946 personen de grootste in Nederland, kwamen vermoedelijk één of twee weigeringen voor. ${ }^{21}$

Telders en Paul Scholten hebben op 13 oktober 1940 bij Seyss-Inquart geprotesteerd tegen de ariërverklaring. Zij stelden dat Nederland geen Jodenvraagstuk kende en ook nooit had gekend. De vraag of beoefenaren van de wetenschap Joden waren of niet, was naar Nederlandse opvatting van geen enkel belang. Meer dan 220 hoogleraren onderschreven dit door Telders en Scholten geïnitieerde protest. De Utrechtse, de Amsterdamse (onder wie Scholten) en de Nijmeegse hoogleraren verstuurden desondanks hun verklaring, zonder enig bezwaar te maken. In Groningen had de hoogleraar in het Romeinse recht J. van Meurs (1889-1945) aanvankelijk op juridische en morele gronden geweigerd het formulier in te

19. Zie over de 'Reichskristallnacht': C.J.H. Jansen, 'Pogroms in Duitsland', NJB 2014, p. 1187 e.v. Zie voorts 'Asylrecht gevraagd', Leeuwarder Courant 17 november 1938, Voorpagina; '71.000 adhesiebetuigingen. Op petitionnement aan minister van Justitie in zake asylrecht', Algemeen Handelsblad 18 november 1938, Ochtendblad, p. 6. De initiatiefnemers waren onder andere de hoogleraren Paul Scholten (1875-1946), W.A. Bonger (1876-1940) en H.R. Hoetink (1900-1963) en de (oud-)raadsheren in de Hoge Raad, A. Fentener van Vlissingen (1862-1951), van 1930 tot 1933 president van dit college, en F. Kranenburg (1870-1949).

20. Verordening 137/1940. Zij hing samen met Verordening 108/1940 die Seyss-Inquart de bevoegdheid gaf ambtenaren te ontslaan. Art. 4 van Verordening 189/1940 bepaalde wie Joods was.

21. Zie J.N.M.E. Michielsen, 'The nazification' and 'denazification' of the courts in Belgium, Luxembourg and the Netherlands, Maastricht: Universitaire Pers Maastricht 2004, p. 130; C. van der Heijden, Grijs verleden. Nederland en de Tweede Wereldoorlog, Amsterdam/Antwerpen: Uitgeverij Contact 2001, p. 140. vullen, maar zijn Joodse collega voor rechtsfilosofie en vriend L. Polak (1880-1941) had hem overgehaald dit toch te doen. De hoogleraar in het strafrecht M.P. Vrij (1895-1955) zond zijn verklaring met een protest in. In Leiden ten slotte had Telders een advies opgesteld, waarin hij hamerde op het feit dat de Nederlandse wetenschap geen onderscheid maakte tussen rassen en de belijders van verschillende geloven. Na veel geharrewar en gedoe hebben de Leidse hoogleraren de ondertekende formulieren toch opgestuurd. Hun protesten hebben Seyss-Inquart zelfs nooit bereikt. ${ }^{22}$

De ambtenaren die op hun formulier hadden aangegeven een joodse herkomst te hebben, werden in november 1940 geschorst in de uitoefening van hun functie. Het bekendste slachtoffer van deze maatregel onder de juridische hoogleraren is de Leidse professor E.M. Meijers (1880-1954) geworden. Cleveringa greep de schorsing van Meijers (en diens collega M. David (1898-1986)) aan om op 26 november 1940 zijn protestrede te houden in het Groot Auditorium van de Leidse universiteit. Deze rede is uitgegroeid tot het symbool van het universitaire verzet tegen de Duitse antisemitische maatregelen tijdens de Tweede Wereldoorlog. ${ }^{23}$ In Delft hadden studenten overigens al op 23 november 1940 geprotesteerd tegen de schorsing van de Joodse buitengewoon hoogleraar in het staatsrecht, A.C. Josephus Jitta (1887-1958). ${ }^{24}$ Naar aanleiding van dit eerste harde signaal van academisch verzet arresteerde de bezetter Cleveringa en Telders. Hij sloot bovendien de universiteit. ${ }^{25}$

Elders heb ik geschreven over het universitaire verzet in Nederland. ${ }^{26}$ Bijna iedere juridische faculteit kende wel een paar moedige hoogleraren. Ik verwijs naar de al genoemde Cleveringa en Telders in Leiden, Van Meurs en Vrij in Groningen, Scholten en D. HazewinkelSuringa (1889-1970) in Amsterdam, V.H. Rutgers (1877-1945) en J. Oranje (1898-1946) aan de VU en

22. Jansen, De Hoge Raad en de Tweede Wereldoorlog, p. 95; W. Otterspeer, Het horzelnest. De Leidse universiteit in oorlogstijd, Amsterdam: Prometheus 2019, p. 100, p. 103 e.v.; J.H.A. Lokin, De Groninger Faculteit der Rechtsgeleerdheid (1596-1970), Den Haag: Boom juridisch 2019, p. 468-469.

23. Zie Kees Schuyt, R.P. Cleveringa. Recht, onrecht en de vlam der gerechtigheid, Amsterdam: Boom uitgevers 2019, p. 179 e.v.; M. Schwegman, 'Cleveringa en Meijers. Een weerbarstige geschiedenis van getuigen en overleven', Cleveringarede 27 november 2017, via internet raadpleegbaar; Otterspeer, Het horzelnest, p. 109 e.v. Cleveringa was overigens niet de enige jurist die protesteerde tegen de schorsing van zijn Joodse collega's. In Amsterdam bijvoorbeeld protesteerden Scholten, Hoetink en I. Kisch (1905-1980).

24. De Delftse studenten gingen - evenals de Leidse - in staking. Hierover: T. Toebosch, Uitverkoren zondebokken. Een familiegeschiedenis, Amsterdam: De Bezige Bij 2010, p. 219 e.v., p. 238 e.v.

25. Het radioprogramma OVT riep de rede van Cleveringa op 25 januari 2015 uit tot de belangrijkste openbare toespraak van de twintigste eeuw in Nederland. Zie Schuyt, R.P. Cleveringa, p. 474. Zie C.J.H. Jansen en W. Rijnenberg, "Slechts de "principieele" houding lijkt mij in dezen "doelmatig". Boekbeschouwing naar aanleiding van Kees Schuyt, R.P. Cleveringa. Recht, onrecht en de vlam der gerechtigheid', Ars Aequi 2019/11, p. 919 e.v.

26. C.J.H. Jansen, 'Het Nederlandse universitaire verzet in de Tweede Wereldoorlog', RMThemis 2020/2. 
W.P.J. Pompe (1893-1968) in Utrecht. In Nijmegen sloot rector B.H.D. Hermesdorf (1894-1978) op 11 april 1943 de deuren van de universiteit. ${ }^{27}$ Deze moedige hoogleraren hebben echter niet kunnen voorkomen dat het universitaire onderwijs lang doorgang heeft gevonden, de Joodse collega's zijn verwijderd van de universiteiten en de Joodse studenten het studeren onmogelijk is gemaakt. ${ }^{28}$ De Nederlandse samenleving kende zoals overal in Europa antisemitisme. Dit anti-Joodse sentiment was vergelijkenderwijs mild en gematigd. Individuen met een Joodse achtergrond werden op een zekere afstand gehouden. ${ }^{29}$ Of onder Nederlandse juridische hoogleraren (sociaal) antisemitisme voorkwam, is moeilijk vast te stellen, maar zij is ongetwijfeld anwezig geweest. ${ }^{30}$

Interessant - tot slot - is het studentenverzet. Daarover is nog steeds relatief weinig bekend. Een belangrijke rol was weggelegd voor het in oktober 1940 gestarte 'illegale' en landelijk verspreide blad De Geus onder Studenten, opgericht, met hulp van hun vader, door de Leidse broers J. (1915-1964) en H. (1917-2004) Drion. ${ }^{31}$ Daarnaast is voor het studentenverzet de vanaf 1942 landelijk opererende Raad van Negen van belang geweest. Het getal negen had betrekking op het aantal steden, waar universiteiten of hogescholen waren gevestigd. De Raad onderhield contact met de redacteuren van De Geus. Op allerlei mogelijke manieren zijn studenten bij het verzet betrokken geraakt, van het verspreiden van verzetskranten en hulp bij het laten onderduiken van Joodse kinde-

27. Ook de Tilburgse Hogeschool sloot haar deuren. Van Rauter mochten de confessionele onderwijsinstellingen hun deuren sluiten, omdat hij niets moest hebben van door kerken aangestuurd onderwijs. Zie Gerritse, Rauter, p. 382-283.

28. Over de bezettingsgeschiedenis van de verschillende universiteiten: J. Bosmans e.a., Tot hier en niet verder! De RK Universiteit in oorlogstijd, Katholieke Universiteit Nijmegen 1993; S. van Walsum, Ook al voelt men zich gewond. De Utrechtse universiteit tijdens de Duitse bezetting, Utrecht: Universiteit Utrecht 1995; F. Broeyer, Het Utrechtse universitaire verzet * Heb je Kafka gelezen? 1940-1945, Utrecht: Stichting Matrijs 2014; P.J. Knegtmans, Een kwetsbaar centrum van de geest. De universiteit van Amsterdam tussen 1935 en 1950, Amsterdam: Amsterdam University Press 1998; G.R. Zondergeld, Geen duimbreed?! De Vrije Universiteit tijdens de Duitse bezetting, Zoetermeer: Meinema 2002; K. van Berkel, Academische illusies. De Groningse universiteit in een tijd van crisis, bezetting en herstel (1930-1950), Amsterdam: Uitgeverij Bert Bakker 2015; Lokin, De Groninger Faculteit der Rechtsgeleerdheid (1596-1970), p. 463 e.v. en Otterspeer, Het horzelnest.

29. C. Quispel, Anti-Joodse beeldvorming en Jodenhaat. De geschiedenis van het antisemitisme in West-Europa, Hilversum: Verloren 2015, p. 214-217; J.C.H. Blom J.J. Cahen, 'Joodse Nederlanders, Nederlandse joden en joden in Nederland (1870-1940)', in: Blom e.a. (red.), Geschiedenis van de Joden in Nederland, p. 324 en p. 330; Otterspeer, Het horzelnest, p. 103.

30. J. Meihuizen, Sans égards. Prof. mr. A. Pitlo en zijn conflicten met Joodse juristen, Amsterdam: Boom 2007, concludeerde op p. 107 van zijn boek dat 'men' zich al met al niet aan de indruk kan onttrekken dat 'Pitlo's conflicten met [C.H.F.] Polak en andere Joodse juristen werden gevoed door antisemitisme'. Ook de Amsterdamse hoogleraar in het oudvaderlands recht L.J. van Apeldoorn (1886-1979) liet zich in antisemitische stereotyperingen uit: de ware aard van het Jodendom was zijn sjachergeest ('Germaansche grondgedachten van Nederlandsch boerenrecht', Nieuw Nederland (juli) 1942, p. 2)

31. Otterspeer, Het horzelnest, p. 147 e.v. ren tot het gewapende verzet. Ik laat het studentenverzet in deze bijdrage verder rusten.

\section{Verzet van de rechterlijke macht tegen de antisemitische maatregelen}

Alle leden van de Hoge Raad hebben de ariërverklaring ingevuld. Alleen J. Donner (1891-1981) krabbelde een (cryptisch) bezwaar op het formulier. ${ }^{32}$ Telders had in een brief president Visser gewaarschuwd voor de consequenties voor het afleggen van een verklaring door de Hoge Raad over het al dan niet Joods zijn. 'Het betreft hier het begin van een zeer ernstige inbreuk op de grenzen, die aan de bezettersbevoegdheid zijn gesteld, een inbreuk die voor tallooze Nederlanders onmetelijke gevolgen kan hebben.' (...) 'Wat thans van ons wordt gevraagd, is de eerste stap voor het verwijderen van niet-Ariërs uit door hen bekleede ambten.' De houding van de Hoge Raad schiep - aldus Telders - een precedent voor alle andere betrokkenen. Hij riep via Visser de raadsheren in de Hoge Raad op 'het groote principieele belang van de zaak niet bij overwegingen van opportuniteit of formalisme achter te stellen' ${ }^{33}$ Telders' oproep aan de Hoge Raad heeft niet mogen baten. Het college 'tekende'. ${ }^{34}$ Uit een naoorlogse brief is naar voren gekomen, dat Visser zich wel degelijk sterk heeft gemaakt voor het niet invullen van de ariërverklaring door de Hoge Raad. Hij is echter 'overruled' door zijn collega's. ${ }^{35}$ De reden waarom zij dit hebben gedaan, komt naar voren in een boekje dat raadsheer N.C.M.A. van den Dries (1880-1958) heeft geschreven ter verdediging van de opstelling van de Hoge Raad. Hij herinnerde zijn lezers aan het feit dat het antisemitisme eerst en vooral een Duitse angelegenheid was geweest. Hij voegde daaraan toe dat ' (...) gelet op de Duitsche mentaliteit en hetgeen het Hitler-regime in Duitschland aan de Joden reeds had misdreven, men zich kan indenken, dat de bezetter in het bijzonder de Joodsche ambtenaren wantrouwde en als gevaarlijk beschouwde. ${ }^{36}$ Het aan de orde stellen van de vervolging van de Joden had daarom weinig zin. Het bracht het voortbestaan van de Hoge Raad in direct gevaar. Was niet protesteren daarom niet

32. C.J.H. Jansen, De Hoge Raad en de Tweede Wereldoorlog. Recht en rechtsbeoefening in de jaren 1930-1950, met medewerking van D. Venema, Amsterdam: Boom 2011, p. 94 e.v.

33. B.M. Telders, 'Zoogenaamde Jodenverklaring', in: Verzamelde Geschriften, IV, p. 363-364.

34. Over de gang van zaken: N.C.M.A. van den Dries, De Hooge Raad der Nederlanden tijdens de bezetting, Leiden: E.J. Brill 1945, p. 42-43; D. Venema, Rechters in oorlogstijd. De confrontatie van de Nederlandse rechterlijke macht met nationaal-socialisme en bezetting, Den Haag: Boom Juridische uitgevers 2007, p. 298-299; Jansen, De Hoge Raad en de Tweede Wereldoorlog, p. 94-96.

35. Zie J. de Ruiter, Jan Donner jurist. Een biografie, Amsterdam: Boom 2003, p. 185, noot 8; M.E. Verburg, 'Mr. L.E. Visser, president van de Hoge Raad in oorlogstijd', NJB 2008, p. 103-1094.

36. N.C.M.A. van den Dries, De Hooge Raad der Nederlanden tijdens de bezetting, Leiden: Brill 1945, p. 43. 
geboden, 'gelet ook op de Regeeringsaanwijzing zoolang mogelijk in functie te blijven?' 37

Van den Dries stond niet alleen in zijn standpunt. De secretaris-generaal voor Justitie, J.J. Schrieke (18841976), een fanatiek NSB'er, heeft altijd geweigerd voor de Joodse Nederlanders op te komen. Kort na de benoeming tot zijn functie, in oktober 1941, had hij een onderhoud met J.P. Hooijkaas (1900-1971) - chef bij de Afdeling Wetgeving - die bij hem kwam protesteren tegen de bedreiging van de Joden. Schrieke reageerde daarop als volgt: ' $U$ bent dit keer voor de Joden opgekomen. $\mathrm{U}$ behoeft in geen enkel geval, op geen enkel moment bij mij te komen voor Joodsche belangen; hiervoor zal ik niets doen. Ik hoop, dat deze verklaring duidelijk is. De verklaring is aldus: $U$ bent een mensch en ik ben een mensch. Menschelijk betreur ik, dat de Joden worden doodgeranseld. Het gaat mij ook ter harte. Dit is een kwestie, die niet tot mijn ressort behoort. Zij behoort niet tot het ressort van het Nederlandsche volk. De Duitsche Regeering neemt het standpunt in, dat de Joden geen onderdeel vormen van het Nederlandsche volk.' 38

De bezetter schorste per 23 november 1940 de negen joodse rechters en/of raadsheren (onder wie Visser) en de 18 joodse rechter- en/of raadsheer-plaatsvervangers. Zij werden ontslagen per 1 maart 1941. De Hoge Raad heeft geen protest aangetekend tegen Vissers ontslag. Ook rechters uit andere rechterlijke instanties hebben zich niet gekeerd tegen het ontslag van hun collega's. ${ }^{39}$

In Nederland is het aantal rechters dat zich op de een of manier heeft verzet tegen het nazi-onrecht, betrekkelijk gering geweest. Ik geef enkele voorbeelden. Hun verzet betrof overigens niet de antisemitische maatregelen van de bezetter. Het Hof Leeuwarden, bestaande uit de raadsheren F.F. Viehoff (1881-1951), J. Wedeven (1884-1853) en J.B.J. Heymeijer (1895-1955), rechtte op 25 februari 1943 zijn rug en keerde zich in een uitspraak tegen de misstanden in het kamp Erica te Ommen. De beroemde overwegingen luidden als volgt:

'(...) dat het Gerechtshof rekening wenscht te houden met de omstandigheid dat sedert eenigen tijd verschillende door den Nederlandschen Rechter aan mannelijken delinquenten opgelegde gevangenisstraffen, in strijd met de wettelijke voorschriften en met de bedoeling van Wetgever en Rechter, zijn of worden ten uitvoer gelegd in gevangeniskampen op zoo strafverzwarende wijze als door den Rechter bij de bepaling van de strafmaat onmogelijk kon worden voorzien of zelfs maar als mogelijk verondersteld; dat

37. Van den Dries, De Hooge Raad der Nederlanden tijdens de bezetting, p. 58; J. Donner, Memoires tot 1946, [ongepubliceerd], p. 86; zie ook Jansen, De Hoge Raad en de Tweede Wereldoorlog, p. 93.

38. Verburg, Geschiedenis van het Ministerie van Justitie 1940-1945, p. 276.

39. Venema, Rechters in oorlogstijd, p. 298-302. De Rechtbank Amsterdam heeft zich sterk gemaakt voor de terugkeer van N. de Beneditty naar de Amsterdamse rechtbank. Tevergeefs. Hij is vermoord in Auschwitz. het Gerechtshof de mogelijkheid van deze wijze van executie der thans op te leggen straf in aanmerking nemend, er zich om des gewetenswille van zal onthouden den verdachte te veroordeelen tot een gevangenisstraf van zoodanigen duur als in casu in evenredigheid zoude staan tot den ernst van het door den verdachte gepleegde misdrijf doch hem zoude blootstellen aan de mogelijkheid van een executie als bovengemeld; (...). ${ }^{40}$

Het voorbeeld van het Hof Leeuwarden kreeg navolging. De Rechtbank Amsterdam stuurde op 15 maart 1943 een brief, waarin zij alle andere rechtbanken en hoven opriepen hun adhesie te betuigen met de uitspraak van het Hof Leeuwarden. De meeste aangeschreven rechterlijke instellingen deden inderdaad een dergelijke verklaring naar secretaris-generaal Schrieke uitgaan. ${ }^{41}$ De strafrechtspraak in Utrecht was al vanaf de tweede week van maart praktisch stilgevallen. De officier van justitie moest de rechters eerst inlichtingen verschaffen over de tenuitvoerlegging van de op te leggen straf. Viehoff, Wedeven en Heymeijer brachten in een uitspraak van 18 maart 1943 een door de Rechtbank Groningen opgelegde gevangenisstraf terug van zes maanden tot zes weken. $\mathrm{Zij}$ hielden opnieuw rekening met de mogelijkheid dat een straf van langere duur op strafverzwarende wijze ten uitvoer zou worden gelegd. ${ }^{42}$ De strafkamer van de Hoge Raad keerde zich op 31 maart 1943 onder expliciete verwijzing naar de uitspraak van het Hof Leeuwarden tegen de wijze van tenuitvoerlegging van de straffen in het kamp Erica te Ommen. ${ }^{43}$

Dezelfde principiële opstelling als het Hof Leeuwarden koos de Arnhemse kortgedingrechter F.J.M. van Nispen tot Sevenaer (1894-1956) die in een uitspraak van 4 september 1944 - anders dan de Hoge Raad in het Toetsingsarrest $^{44}$ - de mogelijkheid tot toetsen door de rechter uitdrukkelijk openliet: 'dat het nu niet uitgesloten lijkt, dat de burgerlijke kamer van de H.R. (...) een van die van 1942 afwijkende beslissing zal geven en toetsing der verordening toelaatbaar zal achten (...). ${ }^{45}$

40. Gepubliceerd in NJ 1951/643. Zie over dit arrest vooral H.L.C. Hermans, Om des gewetens wille. De geschiedenis van een arrest in oorlogstijd, Leeuwarden: Friese Pers Boekerij 2003.

41. Ministerie van Justitie, Kabinetsarchief, inv. nr. 1815 (kamp Erica te Ommen). Vanaf 18 maart stroomden de adhesiebetuigingen van de rechtbanken en de hoven bij secretaris-generaal Schrieke binnen. Hermans, Om des gewetens wille, p. 104 e.v.

42. Ministerie van Justitie, Kabinetsarchief, inv. nr. 1815; brief van A. Semplonius (procureur-generaal bij het Hof Leeuwarden en NSB'er) aan J.J. Schrieke 3 april 1943 (over de tweede uitspraak van Viehoff c.s.) en brief van J.J. Schrieke aan W. Seiffert 27 april 1943 (over de Utrechtse situatie). Hermans, Om des gewetens wille, p. 110 e.v.

43. Nationaal Archief (NA), Hoge Raad 1940-1979, 2.09.65, inv. nr. 2608; zie eveneens Ministerie van Justitie, Kabinetsarchief, inv. nr. 1815. Jansen, De Hoge Raad en de Tweede Wereldoorlog, p. 138.

44. NJ $1942 / 271$

45. NJ 1944/1945, 653. Zie J. Barendsen \& D. Venema, De rechtbank Arnhem en de Duitse bezetting, Nijmegen: Wolf Legal Publishers 2004, p. 59 e.v. 
Een aantal rechters ten slotte nam ontslag. Opnieuw enkele voorbeelden. H. Haga (1885-1965), A.L.M. van Berckel (1890-1973), raadsheren in het Hof Den Haag, en P.G.M. van Meeuwen, rechter bij de Rechtbank Den Haag, vertrokken op 15 oktober 1941, 1 november 1941 en 22 december 1941 als protest tegen de invoering van de vrederechtspraak, een vorm van strafrechtspleging die zich richtte op de berechting van strafbare feiten 'die de politieke vrede binnen de volksgemeenschap' bedreigden of uit politieke beweegredenen waren begaan. ${ }^{46}$ Hun voorbeeld werd in 1943 gevolgd door de procureur-generaal bij de Hoge Raad, W.J. Berger (1883-1953). Hij greep de kwestie van de arbeidsinzet aan om zijn ambt vaarwel te zeggen. In 1944 vertrok Donner uit de Hoge Raad. Hij had gewetensbezwaren tegen de invoering van het leidersbeginsel in de rechtspraak. $^{47}$

\section{Verzet van de advocatuur en het notariaat tegen de antisemitische maatregelen}

De Joodse advocaten moesten per 1 mei 1941 hun werkzaamheden staken. Dit gebeurde met medewerking van Hooykaas en zijn 'baas' secretaris-generaal J.C. Tenkink (1899-1986), de voorganger van Schrieke. Vooral Tenkink had - aldus Meihuizen - 'in het voorjaar van 1941 nauwgezet en op klinische wijze gestalte (...) gegeven aan het beroepsverbod voor Joodse advocaten'. ${ }^{48}$ De Nederlandsche Advocaten-Vereeniging (NAV) heeft niet geprotesteerd tegen het ontslag van de Joodse advocaten. Ook voor veel advocaten gold dat zij zich goed konden indenken dat de bezetter vanwege de nazi-ideologie de Joden wantrouwde: de Duitsers hadden zich in eigen land zo onbehoorlijk tegenover de Joden gedragen dat zij niet konden verwachten dat de Joden betrouwbare ambtenaren zouden zijn. ${ }^{49}$ Meer dan honderd Joodse advocaten van de in totaal tweehonderd Joodse advocaten werden vermoord in nazi-kampen. Gelukkig was er ook verzet van individuele advocaten tegen het antisemitisme en de uitsluiting van de Joden uit het ambt. ${ }^{50}$

46. Ingevoerd bij Verordening 156/1941. Zie uitvoerig Hermans, Om des gewetens wille, p. 21 e.v. en G.Chr. Kok, 'Mr. H. Haga (1885-1965) en Mr. A.L.M. van Berckel (1890-1973). Twee moedige raadsheren tijdens de bezetting en bij de instelling van het Vredegerechtshof', in: G.Chr. Kok, In dienst van het recht. Uit de geschiedenis van het Gerechtshof 's-Gravenhage en de daaraan vooraf gegane hoven (1428-heden), Hilversum: Verloren 2005, p. 125 e.v.

47. De Ruiter, Jan Donner jurist, p. 137 e.v. Zie over de opstelling van de rechters ook C.J.H. Jansen, 'De opstelling van de Nederlandse rechters en raadsheren tijdens de bezetting (naar aanleiding van de uitspraak van het Hof Leeuwarden van 25 maart 1943)', https://trema.nvvr.org/ editie/2018-03/.

48. J. Meihuizen, Smalle marges. De Nederlandse advocatuur in de Tweede Wereldoorlog, Amsterdam: Boom 2010, p. 159, p. 167 e.v., p. 418 (citaat).

49. Meihuizen, Smalle marges, p. 164, p. 419

50. Meihuizen, Smalle marges, p. 178 e.v., p. 424 e.v.: bijlage 2: Omgekomen Joodse Nederlandse advocaten.
Een vijftigtal advocaten heeft zich tijdens de bezetting op bijzondere wijze ingezet voor zijn Joodse medeburgers. De bezetter had namelijk de mogelijkheid geopend om bezwaar te maken tegen iemands registratie als 'Joods'. Een dergelijk bezwaar diende idealiter ertoe te leiden dat iemands Joodse 'afstamming' veranderde in een niet-Joodse, het zogeheten 'ariseren'. Het hoeft nauwelijks betoog dat hiertoe alle middelen - inclusief fraude en bedrog - werden ingezet. De belangrijkste advocaten, die zich met het 'ariseren' bezighielden, waren Y.H.M. Nijgh (1907-1992), A.N. Kotting (1911-1972) en J. van Proosdij (1921-2011). Zij hebben vele Joodse Nederlanders het leven gered. ${ }^{51}$

Tot slot wijs ik erop dat Nederlandse advocaten 'in het verzet' hebben gezeten. Hun precieze aantal is niet bekend. Een van hen was P.W.F. van Till (1906-1945). Hij hielp Joodse mensen bij de onderduik. Hij heeft de oorlog niet overleefd. Op 7 maart 1945 - kort voor de bevrijding - stierf hij in het concentratiekamp Buchenwald door uitputting. ${ }^{52}$

De opstelling van veel notarissen ten opzichte van de antisemitische maatregelen van de Duitse bezetter is ronduit schokkend geweest. $\mathrm{Zij}$ werkten tijdens de oor$\log$ mee aan het ontrechten van de 'Joodse' Nederlanders. De secretaris en de voorzitter van het Hoofdbestuur van de Broederschap der Notarissen, H.W. Schraagen (1898-1977) en Ph.B. Libourel (1878-1954), zorgden in circulaires voor een heldere en praktische uitleg van de antisemitische maatregelen van de bezetter die betrekking hadden op de rol van de notaris bij het vermogensrechtelijk 'kaalplukken' van de Joden. Dat hun gedrag een inbreuk op hun onafhankelijkheid en geheimhoudingsplicht betekende, namen veel notarissen op de koop toe. ${ }^{53}$

De Joodse notarissen moesten - evenals de Joodse advocaten - op 1 mei 1941 hun diensten staken. Zij werden echter al per 21 februari 1941 ontslagen. Libourel probeerde nog van Hooykaas gedaan te krijgen dat de Joodse notarissen als kandidaat-notarissen mochten doorwerken, maar hij kreeg geen enkele medewerking van het Ministerie van Justitie. De Broederschap protesteerde niet tegen het ontslag van haar Joodse leden. ${ }^{54}$ De balans na de bevrijding was dat veel Joodse notarissen niet terugkeerden op hun post. Volgens Schütz wist slechts een enkeling van de weggevoerde notarissen de kampen

51. Meihuizen, Smalle marges, p. 112 e.v., p. 239-241. Daarnaast: G. von Frijtag Drabbe Künzel, Het geval Calmeyer, Amsterdam: Mets \& Schilt 2008 en H.U. Jessurun d'Oliveira (red.), Ontjoodst door de wetenschap. De wetenschappelijke en menselijke integriteit van Arie de Froe onder de bezetting, Amsterdam: Amsterdam University Press 2015, in het bijzonder het artikel van D. Venema, 'Nino Kotting en de arisering van Joodse Nederlanders' (p. 73 e.v.). H.G. Calmeyer (1903-1972), een voormalige Duitse advocaat, was de verantwoordelijke Duitse ambtenaar, die tussen 1941 en 1945 een beslissende rol speelde bij de 'arisering' van Joodse Nederlanders.

52. Meihuizen, Smalle marges, p. 129 e.v. (p. 131).

53. R. Schütz, Kille mist. Het Nederlandse notariaat en de erfenis van de oorlog, Amsterdam: Boom uitgevers 2016, p. 167 e.v., p. 238, p. 212 e.v.

54. Schütz, Kille mist, p. 162 e.v 
te overleven. Hij noemt de Rotterdamse notaris S.S. Wijsenbeek (1879-1968) en zijn vrouw. Van de zestien gedeporteerde Joodse kandidaat-notarissen konden er negen terugkeren naar Nederland. ${ }^{55}$

Een aantal notarissen heeft gekozen voor het verzet, bijvoorbeeld door het ondersteunen van organisaties uit de 'illegaliteit' of door het verlenen van hulp bij de onderduik. Een van hen was de Arnhemse notaris C.M. Böhtlingk (1888-1945). Hij kwam om in Dachau. ${ }^{56} \mathrm{De}$ bezetter had hem vanwege zijn verzetshouding 'oneervol' ontslagen uit zijn ambt. Schütz heeft onlangs - bij het 175-jarige bestaan van de Koninklijke Notariële Beroepsorganisatie in 2018 - opgeroepen dit historische onrecht te herstellen. ${ }^{57}$

\section{Slotopmerkingen}

Het is onmogelijk in deze bijdrage recht te doen aan de opstelling van alle Nederlandse ambtenaren en juristen in de Tweede Wereldoorlog. Ook is het niet mogelijk alle ontwikkelingen te bespreken in zo'n kort stuk als dit. Ik heb enkele hoofdlijnen besproken. Het beeld, dat zich opdringt met betrekking tot de opstelling van de Nederlandse juristen tijdens de bezetting, is weinig verheffend. De praktijk van alledag leek bij de meesten de boventoon te voeren. $\mathrm{Zij}$ protesteerden nauwelijks tegen het ontslag of de verwijdering uit het beroepsleven van hun Joodse collega's. De ariërverklaring werd massaal ingevuld. De mythe van collectieve weerstand is voor de Nederlandse bevolking als geheel vanaf het midden van de jaren zestig van de vorige eeuw bijgesteld naar een minder heroïsch beeld van collectieve aanpassing en passiviteit. ${ }^{58}$ Dat was voor bijvoorbeeld de houding van de Hoge Raad minder nodig. Het college had al in en na de oorlog veel kritiek gekregen vanwege zijn passieve opstelling en het niet protesteren tegen het ontslag van zijn president, Visser. Verklaringen van uit Auschwitz teruggekeerde Joodse Nederlanders, zoals de arts A. Wittenburg, maakten al snel na de bevrijding duidelijk dat er slechts weinig overlevenden waren te verwachten. Zijn verhaal haalde bijna alle kranten. Een kleine berekening had hem geleerd dat, toen hij in februari 1944 in Auschwitz aankwam, al tweeënhalf miljoen joden de 'gasdood' hadden gevonden. Hij vermoedde dat van de ongeveer 95.000 Nederlandse Joden die naar Polen waren vervoerd, er misschien nog maar duizend in leven zouden zijn, 'en ik ben bang, dat

55. Schütz, Kille mist, p. 301 e.v., p. 304 e.v., p. 498, noot 30

56. Schütz, Kille mist, p. 107 e.v.

57. R. Schütz, 'De notariële organisaties en de naoorlogse zuivering van de notariële beroepsgroep', in: C.J.H. Jansen \& J.S.L.A.W.B. Roes (red.), 175 jaar KNB, Den Haag: Sdu Uitgevers 2018, p. 52. De verantwoordelijke Minister heeft de familie in een brief laten weten dat het ontslag 'eervol' had moeten zijn.

58. H. Piersma \& J. Kemperman, Openstaande rekeningen. De gemeente Amsterdam en de gevolgen van roof en rechtsherstel, 1940-1950, Amsterdam: Boom 2015, p. 18 e.v. dit cijfer nog te hoog zal zijn'. ${ }^{59}$ De berichten zullen hopelijk sommige juristen hebben aangezet tot reflectie op de eigen opstelling.

Van verzet tegen de antisemitische maatregelen is slechts in bescheiden mate sprake geweest. Protest tegen het gezag paste niet bij de voorstelling die de meeste ambtenaren en juristen hadden van hoe zij behoorden te functioneren. $\mathrm{Zij}$ waren niet opgeleid in tegenspraak. De hoogste ambtenaren in Nederland, de secretarissengeneraal, hebben bovendien een verzetshouding niet aangemoedigd. Hun motto was - evenals dat van de Nederlandse regering - zo lang mogelijk doorwerken in het belang van het Nederlandse volk. De Hoge Raad zweeg. De vertegenwoordigende organisaties, zoals de NAV en de Broederschap, zwegen. Toen Rijkscommissaris Seyss-Inquart in het voorjaar van 1941 zijn masker liet vallen, werd het bieden van verzet 'levensgevaarlijk' . Terreur kreeg Nederland in haar greep. De deportaties van de Joodse burgers stonden op het punt van beginnen. Deze context maakte het optreden van hen die zich wel hebben gekeerd tegen het antisemitisme en de Jodenvervolging, nog bewonderingswaardiger. $\mathrm{Na}$ de bevrijding is dit wel eens vergeten.

59. 'Massamoord op Nederlandse Joden', Het Vrije Volk 9 juni 1945, p. 2 'De massamoord op Nederlandse Joden', Het Binnenhof 11 juni 1945 voorpagina; 'Een Nederlandsche arts uit het concentratiekamp Auswitz teruggekeerd. De massamoord op Nederlandsche joden', Vrije Stemmen, Dagblad voor Zeeland 20 juni 1945, voorpagina; 'De hel van Auswitz. Teruggekeerde arts over massamoord op Ned. Joden', Het Nieuws 16 juni 1945, p. 2. Een andere uit Auschwitz teruggekeerde arts, E. Zeldenrust, kwam met dezelfde cijfers. Het Parool van 5 februari 1945 (Nieuwsbulletin No. 66), p. 2, bevatte een van de eerste berichten over de bevrijding van het concentratiekamp te Oswiecim (Auschwitz). De Russen hadden er enige duizenden totaal uitgeputte mensen aangetroffen van wie de leeftijd niet meer was vast te stellen. Een deel van het kamp was, aldus de Russen, 'geheel ingericht voor het dooden van menschen'. 